\title{
Penyelesaian Perkara Lalu Lintas Berbasis Elektronik dalam Upaya Mengurangi Penumpukan Perkara Dan Pungutan Liar
}

\author{
Jupri Jupri' ${ }^{1}$, Yoslan Koni' ${ }^{2},{ }^{\Omega}$ Roy Marthen Moonti ${ }^{2}$, \\ ${ }^{1}$ Fakultas Hukum, Universitas Ichsan Gorontalo \\ ${ }^{2}$ Fakultas Hukum, Universitas Gorontalo \\ ${ }^{\Omega}$ Surel Koresponden: roymoonti16@gmail.com
}

\begin{abstract}
:
The purpose of this study is to determine the implementation of electronicbased traffic case resolution in the regions to determine the obstacles in solving electronic-based traffic cases. This type of research uses empirical research. The type of research used in this research is empirical research. Implementation of electronic-based traffic case settlement in the regions, where the offender receives a ticket ID via SMS, then makes a transfer via a bank account. After that, bring proof of e-ticket payment to the district attorney to exchange the confiscated evidence, then the offender gets a ticket ID via SMS, the offender goes to the district court to attend the trial and pay there and the offender receives the ticket ID via SMS. Offenders come to the court to see the announcement of the traffic court and the court directs to pay at the prosecutor's office and the obstacles to solving electronic-based traffic cases, namely legal factors, social factors and community factors. In the implementation of the settlement of traffic cases in the future, this should be stated in the law so that its application can still be clearer, then more in-depth socialization is also needed regarding the prosecution process so that the public will be able to understand.
\end{abstract}

Keywords: settlement of cases; traffic; e-ticket; illegal fees;

\begin{abstract}
Abstrak:
Tujuan penelitian ini untuk mengetahui pelaksanaan penyelesaian perkara lalu lintas berbasis elektronik di daerah untuk mengetahui hambatanhambatan penyelesaian perkara lalu lintas berbasis elektronik. Jenis penelitian ini menggunakan jenis penelitian empiris. Jenis penelitian yang digunakan dalam penelitian ini jenis penelitian empiris. Pelaksanaan penyelesaian perkara lalu lintas berbasis elektronik di daerah yaitu pelanggar menerima ID Tilang melalui SMS, kemudian melakukan transfer melalui rekening bank. Setelah itu membawa bukti pembayaran e-Tilang ke kejaksaan negeri untuk ditukar dengan barang bukti yang disita, kemudian si Pelanggar mendapatkan ID Tilang melalui SMS, si pelanggar ke pengadilan negeri untuk mengikuti sidang dan membayar disana dan si pelanggar menerima ID Tilang melalui sms. Pelanggar mendatangi pengadilan untuk melihat pengumuman sidang lalu lintasdan pihak pengadilan mengarahkan untuk membayar di kejaksaan dan hambatan-hambatan penyelesaian perkara lalu lintas berbasis elektronik yaitu faktor hukum, faktor social dan faktor masyarakat. Dalam pelaksanaan penyelesaian perkara lalu lintas kedepan seharusnya ini dituangkan di dalam undang undang sehingga penerapannya masih bisa lebih jelas, kemudian juga dibutuhkan sosialisasi yang lebih mendalam terkait dengan proses penindakannya sehingga masyarakat akan bisa memahami.
\end{abstract}

Kata Kunci: penyelesaian perkara; lalu lintas; e-tilang; pungutan liar; 


Submit : 19-11-2020 Accept : 26-11-2020

Doi: http://doi.org/10.56087/aijih.v23i2.52

\section{PENDAHULUAN}

Keberadaan hukum dan negara dalam konsepsi negara hukum merupakan dua sisi yang tidak dapat dipisahkan antara satu dengan yang lainnya. Hal ini di karenakan suatu negara yang mengkultuskan sistem ketatanegaraannya sebagai negara hukum tentunya tidak dapat dipisahkan dari eksistensi hukum dalam penyelenggaraan negara dan pemerintahan di negara tersebut. Negara hukum merupakan konsep bernegara yang telah berkembang dari beberapa dekade lalu. Terbukti dari keberadaan pemikiran mengenai konsep-konsep negara hukum yang telah ada dan berkembang jauh sebelum konsep negara hukum telah tersusun dan tertata seperti saat sekarang ini. ${ }^{1}$

Lahirnya Undang-Undang Nomor 2 Tahun 2002 tentang Kepolisian Republik Indonesia tidak lain sebagaiamana dalam konsideran menimbang. Pertama, bahwa keamanan dalam negeri merupakan syarat utama mendukung terwujudnya masyarakat madani yang adil, makmur, dan beradab berdasarkan Pancasila dan Undang-Undang Dasar Negara Republik Indonesia Tahun 1945.

Kedua, bahwa pemeliharaan keamanan dalam negeri melalui upaya penyelenggaraan fungsi kepolisian yang meliputi pemeliharaan keamanan dan ketertiban masyarakat, penegakan hukum, perlindungan, pengayoman, dan pelayanan kepada masyarakat dilakukan oleh Kepolisian Negara Republik Indonesia selaku alat negara yang dibantu oleh masyarakat dengan menjunjung tinggi hak asasi manusia.

Ketiga, bahwa telah terjadi perubahan paradigma dalam sistem ketatanegaraan yang menegaskan pemisahan kelembagaan Tentara Nasional Indonesia dan Kepolisian Negara Republik Indonesia sesuai dengan peran dan fungsi masing-masing. Terakhir, bahwa Undang-Undang Nomor 28 Tahun 1997 tentang Kepolisian Negara Republik

${ }^{1}$ Nuna, M., Moonti, R. M., Tumuhulawa, A., \& Kodai, D. A. (2020). Kewenangan Penyelesaian Sengketa Tata Usaha Negara Terhadap Putusan Pemberhentian Tidak Dengan Hormat. University Of Bengkulu Law Journal, 5(2), 106-118. h, 107 
Indonesia sudah tidak memadai dan perlu diganti untuk disesuaikan dengan pertumbuhan dan perkembangan hukum serta ketatanegaraan Republik Indonesia.

Bila merujuk pada poin menimbang ke (2) sebagaimana dijabarkan lebih jauh dalam Pasal 5 ayat 1 UU Nomor 2 Tahun 2002 menyatakan bahwa "Kepolisian Negara Republik Indonesia merupakan alat negara yang berperan dalam memelihara keamanan dan ketertiban masyarakat, menegakkan hukum, serta memberikan perlindungan, pengayoman, dan pelayanan kepada masyarakat dalam rangka terpeliharanya keamanan dalam negeri."2

Terkhusus tugas penegakan hukum bagi pelanggaran lalu lintas termaktub dalam poin (b) menyelenggarakan segala kegiatan dalam menjamin keamanan, ketertiban, dan kelancaran lalu lintas di jalan. Artinya bahwa Kepolisian Republik Indonesia memiliki kewenangan dalam pengaturan lalu lintas dan penindakan terhadap pelanggaran lalu lintas dan angkutan jalan. ${ }^{3}$

Lalu lintas dan angkutan jalan adalah kebutuhan yang mendasar dari setiap orang yang berinteraksi sosial, oleh karena untuk mendapatkan atau menciptakan kondisi lalu lintas yang aman, selamat, tertib, dan lancar diperlukan etika dan sopan santun lalu lintas, agar tertanam dalam diri pribadi sebagai suatu nilai. ${ }^{4}$

Untuk menjamin agar undang-undang dan peraturan lalu lintas yang diatur dalam Undang-Undang Nomor 22 Tahun 2009 tentang Lalu Lintas dan Angkutan Jalan dapat ditaati, terdapat ancaman hukuman didalamnya terhadap setiap orang yang melanggar ketentuan undang-undang lalu lintas. Namun, sekalipun sudah ada aturan yang mengatur tentang lalu lintas dan angkutan jalan dengan jelas, lengkap, dan ancaman hukuman yang lebih berat, tetap saja masih ada sebagian masyarakat yang tidak mau patuh pada aturan tersebut.

Untuk penegakan hukum atas pelanggaran dan kejahatan lalu lintas, maka berdasarkan Pasal 267 UU Nomor 22 Tahun 2009 tentang Lalu Lintas dan Angkutan

\footnotetext{
2 Lihat Pasal 14 Undang-Undang Nomor 2 Tahun 2002 tentang Kepolisian Republik Indonesia

3 Putra, R. H. W. (2020). Peran E-Tilang dalam Penindakan Pelanggaran Lalu Lintas Guna Mewujudkan Kamseltibcar Lantas di Wilayah Hukum Polres Banyumas. Police Studies Review, 4(1), 373-416. h, 396

${ }^{4}$ Mulyono, A. T., \& Sandra, P. A. (2013). Evaluasi Kendala Dan Masalah Implementasi UU 22/2009 Tentang Llaj Terhadap Capaian Penyelenggaraan Jalan Nasional. Jurnal Transportasi, 13(2).
} 
Jalan bagi setiap pelanggar diperiksa menurut "Acara Pemeriksaan Cepat". Dimana sidang dengan sistem acara pemeriksaan cepat bisa dilakukan tanpa hadirnya pelanggar (in absentia).

Akan tetapi, berdasarkan laporan akhir penelitian alternatif pengelolaan perkara pelanggaran lalu lintas di pengadilan oleh PSHK Indonesia, Puslitbang Hukum dan Peradilan MA, dan Australia Indonesia Patnership for Justice tahun 2015 menyatakan bahwa data perkara dalam Laporan Tahunan Mahkamah Agung Tahun 2013 menunjukkan perkara pelanggaran lalu lintas merupakan jenis perkara pidana terbesar yang ditangani oleh pengadilan negeri. Total jumlah perkara pidana yang ditangani pengadilan negeri pada 2013 berjumlah 3.386.149 perkara. Sebanyak 3.214.119 atau 96,40\% merupakan perkara tindak pidana ringan dan pelanggaran lalu lintas. Perkara pidana biasa pada 2013, sebesar 119.876 atau 3,60\%. Sisanya merupakan perkara pidana singkat sebesar 231 perkara atau 0,01\%.5

Sidang tilang diberbagai daerah ruet dan semraut, dan diharapkan ke depan sidang tilang tidak usah sampai ke pengadilan. Selain itu, sidang tilang yang dilakukan setiap hari jumat sangatlah rawan lahirnya percaloan. ${ }^{6}$ Selain rawan terjadi pencaloan dalam pengurusan sidang tilang, praktek-praktek pungutan liar (Pungli) pun banyak terjadi di lapangan. ${ }^{7}$ Kepolisian Republik Indonesia merilis bawah terdapat 235 kasus pungutan liar (pungli) yang melibatkan oknum polisi dalam kurung waktu tiga bulan, yakni dari 17 Juli sampai 17 Oktober 2016. Berdasarkan data tersebut Satuan Lalu Lintas menempati urutan pertama dalam kasus pungutan liar yakni sebanyak 160 kasus. Kemudian disusul oleh Reserse Kriminal sebanyak 26 kasus, Baharkam 39 kasus dan fungsi Intel 10 kasus. $^{8}$

5 Ginting, M. S., Suharyanto, B., Nugroho, E., Taufik, G. A., Damayana, G. P., Sholikin, M. N., ... \& Argama, R. (2015). Standardisasi Pengelolaan Perkara Pelanggaran Lalu Lintas di Pengadilan Negeri. Indonesian Center for Law and Policy Studies.

$6 \quad$ https://news.detik.com/berita/d-2225696/banyak-calo-sidang-tilang-perlu-dievaluasi-

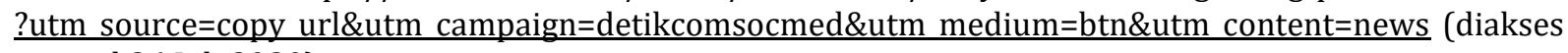
tanggal 26 Juli 2020)

${ }^{7}$ Setiyanto, S., Gunarto, G., \& Wahyuningsih, S. E. (2017). Efektivitas Penerapan Sanksi Denda E-Tilang Bagi Pelanggar Lalu Lintas Berdasarkan Undang-Undang Nomor 22 Tahun 2009 Tentang Lalu Lintas Dan Angkutan Jalan (Studi Di Polres Rembang). Jurnal Hukum Khaira Ummah, 12(4), 742-766. h, 744

${ }^{8}$ Yantina Debora, (2020). https://tirto.id/bVCo?utm source=CopyLink\&utm medium=Share, (diakses tanggal 4 Agustus 2020). 
Oleh sebab itu, pada tanggal 9 Desember 2016, Ketua Mahkamah Agung Republik Indonesia Muhammad Hatta Ali menetapkan lahirnya Peraturan Mahkamah Agung (PERMA) Nomor 12 Tahun 2016 tentang Tata Cara Penyelesaian Perkara Pelanggaran Lalu Lintas. Dimana memperkenalkan istilah penyelesaian perkara pelanggaran lalu lintas elektronik adalah proses peradilan perkara pelanggaran lalu lintas yang diselenggarakan secara terpadu berbasis elektronik melalui dukungan sistem informasi dan teknologi, model ini merupakan penyelesaian perkara lalu lintas berbasis elektronik. 9,10

PERMA Nomor 12 Tahun 2016 didasarkan atas pertimbangan yakni (1) bahwa pelayanan pengadilan adalah dalam rangka pemenuhan kebutuhan masyarakat khususnya pencari keadilan yang diselenggarakan oleh Mahkamah Agung dan badan peradilan di bawahnya berdasarkan peraturan perundangundangan dan prinsipprinsip pelayanan publik. (2) bahwa penyelesaian dan pengelolaan perkara pelanggaran lalu lintas tertentu selama ini tidak optimal sehingga perlu dilakukan pengaturan agar keadilan dan pelayanan publik dapat dirasakan oleh masyarakat atau pencari keadilan.

\section{METODE}

Jenis Penelitian dalam penelitian ini adalah yuridis empiris yang dengan kata lain adalah jenis penelitian hukum sosiologis dan dapat disebut pula dengan penelitian lapangan, yaitu mengkaji ketentuan hukum yang berlaku serta apa yang terjadi dalam kenyataan di masyarakat. ${ }^{11}$

\section{HASIL}

\section{Pelaksanaan Penyelesaian Perkara Lalu Lintas Berbasis Elektronik di Daerah}

Undang-Undang Nomor 22 Tahun 2009 tentang Lalu Lintas dan Angkutan Jalan sebagaimana pada Pasal 3 menyatakan bahwa Lalu Lintas dan Angkutan Jalan diselenggarakan dengan tujuan. Pertama, terwujudnya pelayanan Lalu Lintas dan

\footnotetext{
9 Fansuri, A. (2019). Sistem Tilang Elektronik terhadap Pelanggar Lalu Lintas Berdasarkan Perma Nomor 12 Tahun 2016. Ijtihad, 34(2).

10 Wahyuningsih, S. E., \& Iksan, M. (2019, November). The Benefits of the E-Traffic Ticketing (E-Tilang) System in the Settlement of Traffic Violation in Indonesia. In 2nd International Conference on Indonesian Legal Studies (ICILS 2019) (pp. 447-452). Atlantis Press. h, 448

11 Waluyo, B. (1991). Penelitian hukum dalam praktek. Sinar Grafika, Jakarta. h, 15
} 
Angkutan Jalan yang aman, selamat, tertib, lancar, dan terpadu dengan moda angkutan lain untuk mendorong perekonomian nasional, memajukan kesejahteraan umum, memperkukuh persatuan dan kesatuan bangsa, serta mampu menjunjung tinggi martabat bangsa. Kedua, terwujudnya etika berlalu lintas dan budaya bangsa. Ketiga, terwujudnya penegakan hukum dan kepastian hukum bagi masyarakat.

Tujuan pada poin (3) yakni adanya frasa "terwujudnya penegakan hukum". Artinya bahwa Pelanggaran lalu lintas merupakan tindak pidana yang paling banyak terjadi dalam masyarakat. Tingginya mobilitas masyarakat berbanding lurus dengan peningkatan jumlah kendaraan bermotor. Baik kendaraan bermotor umum yang mengangkut manusia, maupun kendaraan bermotor khusus, misalnya truk, kontainer sebagai alat angkut barang. Adapun tingginya pelangaran lalu lintas di wilayah hukum Pengadilan Negeri Gorontalo tergambar pada tabel berikut:

\section{Tabel 1}

Pelanggaran Lalu Lintas bulan Juli 2020

\begin{tabular}{lll}
\hline No & Jumlah Perkara Lalu Lintas & Jenis Sanksi \\
\hline $\mathbf{1}$ & 270 Perkara & Denda \\
\hline & Data Pengadilan Negeri Gorontalo, diolah tahun 2020
\end{tabular}

Berdasarkan data pada tabel 1 di atas, terlihat jelas banyaknya pelanggaran lalu lintas yang di sidangkan di Pengadilan Negeri Gorontalo. Untuk bulan Juli 2020 saja, perkara yang diperiksa melalui peradilan cepat berjumlah 270 perkara. Tingginya jumlah perkara yang ditangani disebabkan karen untuk wilayah hukum Pengadilan Negeri Gorontalo menangani pelanggaran lalu lintas dan angkutan jalan untuk wilayah Kota Gorontalo bersama Kabupaten Bone Bolango.

Tingginya pelanggaran lalu lintas yang ditangani pengadilan negeri, sehingga pada tahun 2016, Ketua Mahkamah Agung menerbitkan Peraturan Mahkamah Agung Nomor 12 Tahun 2016 tentang Tata Cara Penyelesaian Perkara Lalu Lintas. Pasal 1 butir 2 berbunyi penyelesaian Perkara Pelanggaran Lalu Lintas Elektronik adalah proses peradilan perkara pelanggaran lalu lintas yang diselenggarakan secara terpadu berbasis elektronik melalui dukungan sistem informasi dan teknologi. 
Wilayah hukum Pengadilan Negeri Gorontalo pun PERMA Nomor 12 Tahun 2016 telah diberlakukan. Penyelesaian perkara lalu lintas berbasis elektronik telah diterapkan di wilayah hukum Pengadilan Negeri Gorontalo pada tahun 2017.12 Walaupun masih tetap saja, masyarakat pelanggar lalu lintas mengikuti persidangan pada hari jumat di pengadilan, meskipun sudah ada mekanisme penyelesaian tilang secara elektronik.

\section{a. Elektronik Tilang (e-Tilang)}

Muatan konsideran menimbang UU Nomor 22 Tahun 2009 tentang Lalu Lintas dan Angkutan Jalan menyatakan bahwa lalu lintas dan angkutan jalan mempunyai peran strategis dalam mendukung pembangunan dan integrasi nasional sebagai bagian dari upaya memajukan kesejahteraan umum sebagaimana diamanatkan oleh UndangUndang Dasar Negara Republik Indonesia Tahun 1945. Olehnya, sebagai bagian dari sistem transportasi nasional harus dikembangkan potensi dan perannya untuk mewujudkan keamanan, keselamatan, ketertiban, dan kelancaran berlalu lintas dan angkutan jalan dalam ranga mendukung pembangunan ekonomi dan pengembangan wilayah.

Seiring perkembangan lingkungan strategis nasional dan internasional menuntut penyelenggaraan lalu lintas dan angkutan jalan yang sesuai dengan perkembangan ilmu pengetahuan dan teknologi, otonomi daerah, serta akuntabilitas penyelenggaraan negara. Pada konsideran menimbang juga menyebutkan pentingnya perkembangan ilmu pengetahuan dan teknologi dalam rangka menunjang terlaksananya tertib berlalu lintas. Di saat yang sama mendorong terciptanya akuntabilitas penyelenggaraan negara. Pasal 1 angka 13 Undang-Undang Nomor 22 Tahun 2009 memberikan definisi sistem informasi dan komunikasi lalu lintas dan angkutan jalan adalah sekumpulan subsistem yang saling berhubungan dengan melalui penggabungan, pemrosesan, penyimpanan, dan pendistribusian data yang terkait dengan penyelenggaraan lalu lintas dan angkutan jalan. Artinya dimungkinkan adanya suatu sistem penyelesaian perkara lalu lintas dan angkutan jalan yang berbasis elektronik.

12 Data Primer, Hasil Wawancara pada salah satu Hakim Pengadilan Negeri Gorontalo, Ngguli Liwar Mbani Awang, pada tanggal 24 Juli 2020 
Pada tanggal 9 Desember 2016, Ketua Mahkamah Agung Republik Indonesia Muhammad Hatta Ali menetapkan lahirnya Peraturan Mahkamah Agung (PERMA) Nomor 12 Tahun 2016 tentang Tata Cara Penyelesaian Perkara Pelanggaran Lalu Lintas. Dimana memperkenalkan istilah penyelesaian perkara pelanggaran lalu lintas elektronik adalah proses peradilan perkara pelanggaran lalu lintas yang diselenggarakan secara terpadu berbasis elektronik melalui dukungan sistem informasi dan teknologi. Model ini merupakan penyelesaian perkara lalu lintas berbasis elektronik.

PERMA Nomor 12 Tahun 2016 didasarkan atas pertimbangan yakni (1) bahwa pelayanan pengadilan adalah dalam rangka pemenuhan kebutuhan masyarakat khususnya pencari keadilan yang diselenggarakan oleh Mahkamah Agung dan badan peradilan di bawahnya berdasarkan peraturan perundang-undangan dan prinsipprinsip pelayanan publik. (2) bahwa penyelesaian dan pengelolaan perkara pelanggaran lalu lintas tertentu selama ini tidak optimal sehingga perlu dilakukan pengaturan agar keadilan dan pelayanan publik dapat dirasakan oleh masyarakat atau pencari keadilan.

Penyelesaian perkara lalu lintas berbasis elektronik ini sebagaimana diatur dalam PERMA Nomor 12 Tahun 2016, lazim disebut tilang elektronik (e-Tilang). Seiring dengan kemajuan teknologi dan informasi, kini tilang telah menggunakan sistem elektronik yang salah satunya dikenal dengan sistem e-Tilang, dan diharapkan seluruh proses tilang akan lebih efektif dan efisien juga membantu pihak kepolisian dalam manajemen administrasi. ${ }^{13}$ Sistem e-Tilang yang dimaksud dalam penelitian ini akan menggantikan sistem tilang manual yang menggunakan blanko/surat tilang, dimana pengendara yang melanggar akan dicatat melalui aplikasi yang dimiliki personil kepolisan. Dengan adanya e-Tilang tersebut membuat masyarakat untuk membayar denda melalui bank, sehingga peluang oknum kepolisian untuk melakukan pungutan liar menjadi kecil atau bahkan tidak ada. Namum, tidak semua masyarakat dapat mengikuti prosedur prosedur e-Tilang yang diberikan oleh

${ }^{13}$ Sitepu, C., Rifai, E., \& Jatmiko, G. (2019). Analisis Pelaksanaan E-Tilang Dalam Upaya Pencegahan Praktik Pungutan Liar Yang Dilakukan Oleh Polisi Lalu Lintas (Studi Polres Metro Jakarta Selatan). POENALE: Jurnal Bagian Hukum Pidana, 7(2). h, 6 
kepolisian, terutama untuk masyarakat awam yang kurang mengerti tentang teknologi.

Aplikasi e-tilang merupakan inovasi dari Korlantas Polri dalam meningkatan pelayanan pembayaran denda pelanggaran lalu lintas berbasis TI (Teknologi Informasi), pembuatan aplikasi e-tilang terintegrasi dengan instansi terkait yang telah disepakati dan dikoordinasikan antara Korps Lalu Lintas (Korlantas) Kepolisian RI, Mahkamah Agung RI, Kejaksaan Agung RI., dan PT. Bank Rakyat Indonesia (Persero) Tbk. Aplikasi tersebut terdiri dari 26 kolom yang diisi oleh masing-masing instansi dengan kewenangan masing masing dengan proses pengelolaan data perkara pelanggaran lalu lintas/tilang dengan menggunakan aplikasi tilang online. ${ }^{14}$

Hasil penelitian penulis, penerapan e-Tilang memiliki manfaat yang sangat besar. Pertama, mengurangi penumpukan perkara pelanggaran lalu lintas di pengadilan. Karena berbicara soal Pengadilan Negeri Gorontalo khusus untuk perkara tindak pidana, memeriksa dan mengadili pelimpahan berkas perkara dari 2 (dua) wilayah hukum kejaksaan negeri, yakni Kejaksaan Negeri Kota Gorontalo dan Kejaksaan Negeri Bone Bolango. Sehingga dapat ditarik kesimpulan bahwa Pengadilan Negeri Gorontalo pastinya memeriksa banyak perkara bukan hanya pidana termasuk pula perkara perdata. Khusus untuk perkara Lalu Lintas penumpukan perkara bisa kita dilihat sebagai berikut:

\section{Tabel 2}

Pelanggaran Lalu Lintas bulan Juli 2020

\begin{tabular}{lll}
\hline No & Jumlah Perkara Lalu Lintas & Jenis Sanksi \\
\hline $\mathbf{1}$ & 270 Perkara & Denda \\
\hline
\end{tabular}

Data Pengadilan Negeri Gorontalo, diolah tahun 2020

Berdasarkan tabel di atas, terlihat jelas bahwa untuk per 1 Juli sampai 21 Juli perkara khusus pelanggaran lalulintas yang ditangani oleh Pengadilan Negeri Gorontalo

${ }^{14}$ Apriliana, L. Z., \& Jaya, N. S. P. (2019). Efektivitas Penggunaan E-Tilang Terhadap Pelanggaran Lalu Lintas Di Polres Magelang. Jurnal Komunikasi Hukum, 5(2). h. 5 
berjumlah 270 perkara. Dengan jenis sanksi pidana yang dikenakan adalah denda. Dari 270 perkara pelanggaran lalu lintas yang diperiksa dan diadili oleh Pengadilan Negeri Gorontalo, khusus untuk pelanggaran lalu lintas yang merupakan wilayah hukum Polres Bone Bolango berjumlah 129. Adapun secara jelas jenis profesi pelanggarnya bisa dilihat pada tabel 3 .

\section{Tabel 3}

Pelanggar Lalu Lintas Dari Segi Profesi

\begin{tabular}{lcccccc}
\hline No & ASN & Swasta & Mahasiswa & Siswa & Pengemudi & Lain2 \\
\hline $\mathbf{1}$ & 9 & 81 & 18 & 6 & 4 & 11 \\
\hline Total & \multicolumn{7}{c}{$\mathbf{1 2 9}$} & & & & \\
\hline
\end{tabular}

Data Polres Bone Bolango, diolah tahun 2020

Adapun yang dapat ditarik kesimpulan berdasarkan hasil penelitian sebagaimana tersaji dalam tabel 2 dan tabel 3 yakni perkara yang paling banyak masuk ke Pengadilan Negeri Gorontalo adalah perkara lalu lintas. Terlihat untuk bulan Juli totalnya adalah 270 perkara yang terdiri dari 129 perkara lalu lintas di Bone Bolangodan 141 perkara lalu lintas di Kota Gorontalo.

Setelah berlakunya PERMA Nomor 12 Tahun 2016 yang mulai diterapkan di Pengadilan Negeri Gorontalo pada tahun 2017 sedikit mengurangi penumpukan perkara lalu lintas yang disidangkan setiap hari jumat di pengadilan. Walaupun belum optimal, terbukti dengan masih banyaknya masyarakat yang memilih untuk ikut sidang, padahal masyarakat tidak mesti harus hadir dan cukup melihat situs yang telah kami sediakan. ${ }^{15}$

Kedua, menghilangkan terjadinya percaloan. Sebagaimana hasil penelitian yang penulis lakukan bahwa untuk perkara lalu lintas dalam satu bulan saja bisa mencapai 270 perkara. Artinya dalam setahun bisa mencapai ribuan perkara pelanggaran lalu lintas. Tingginya perkara yang masuk di Pengadilan Negeri Gorontalo, mau tidak mau

15 Data Primer, Hasil Wawancara pada salah satu Hakim Pengadilan Negeri Gorontalo, Ngguli Liwar Mbani Awang, pada tanggal 24 Juli 2020. 
menumbuhkan praktik percaloan. Karena pelanggar dari ragam profesi sebagaimana tabel 3 di atas, tentu memiliki kesibukan masing-masing. Pada titik inilah calo sidang pengadilan untuk perkara lalu lintas bermunculan. Sebab pelanggaran lalu lintas bersifat in absentia atau diperiksa tanpa hadirnya si pelanggar.

Ketiga, meminimalisir terjadinya pungatan liar. Pelanggaran lalu lintas merupakan tindak pidana yang umum terjadi di masyarakat. Olehnya sangatlah mudah melihat praktek-praktek pungutan liar di jalan yang lazim di sebut "atur damai". Hampir semua pelanggar lalu lintas yang melakukan praktek "atur damai” disebabkan karena kesibukan atau tidak ingin berurusan dengan pengadilan.

Pungutan liar masuk sebagai salah satu bentuk tindak pidana korupsi yang diatur dalam UU Nomor 31 Tahun 1999 Jo. UU Nomor 20 Tahun 2001 tentang Pemberantasan Tindak Pidana Korupsi. ${ }^{16}$ Pertama, pegawai negeri atau penyelenggara negara yang memeras. Pasal 12 huruf e berbunyi "Pegawai negeri atau penyelenggara negara yang dengan maksud menguntungkan diri sendiri atau orang lain secara melawan hukum, atau dengan menyalahgunakan kekuasaannya memaksa seseorang memberikan sesuatu, membayar, atau menerima pembayaran dengan potongan, atau untuk mengerjakan sesuatu bagi dirinya sendiri, dipidana dengan pidana penjara seumur hidup atau pidana penjara paling singkat 4 (empat) tahun dan paling lama 20 (dua puluh) tahun dan pidana denda paling sedikit Rp. 200.000.000 (dua ratus juta rupiah) dan paling banyak Rp. 1.000.000.000 (satu miliar rupiah).

Kedua, masih termasuk pemerasan yang dilakukan oleh pegawai negeri atau penyelenggara negara. Perbedaannya terletak pada ada tidaknya unsur "memaksa" dan unsur "pada waktu menjalankan tugas". Sebagaimana Pasal 12 huruf g berbunyi "Pegawai negeri atau penyelenggara negara yang pada waktu menjalankan tugas, meminta atau menerima pekerjaan, atau penyerahan barang, seolah-olah merupakan utang kepada dirinya, padahal diketahui bahwa hal tersebut bukan merupakan utang, dipidana dengan pidana penjara seumur hidup atau pidana penjara paling singkat 4 (empat) tahun dan paling lama 20 (dua puluh) tahun dan pidana denda

16 Suhariyanto, B. (2015). Penerapan Diversi untuk Menangani Problema Penyelesaian Perkara Pelanggaran Lalu Lintas di Pengadilan. Jurnal Hukum dan Peradilan, 4(1), 153-170. h, 155 
paling sedikit Rp. 200.000.000 (dua ratus juta rupiah) dan paling banyak Rp. 1.000.000.000 (satu miliar rupiah).

Oleh sebab itu, lahirnya konsep e-Tilang sangatlah tepat untuk meminimalisir praktek-praktek pungutan liar di jalan. Mengapa e-Tilang mengurangi praktek pungutan liar karena penyelesaian perkaranya berbasis elektronik. Si Pelanggar cukup ke bank membayar jumlah denda, kemudian menukar bukti pembayaran dengan barang bukti pelanggar yang disita. Artinya tidak ada lagi pelanggar yang harus ke pengadilan. Semuanya cukup dengan basis elektronik.

Keempat, mempercepat penyelesaian perkara. E-Tilang merupakan bentuk penyelesaian perkara lalu lintas berbasis elektronik. Konsep e-Tilang sangat sejalan dengan asas peradilan cepat dalam hukum acara pidana. Apalagi telah kita ketahui bahwasanya pelanggaran lalu lintas itu disamakan dengan tindak pidana ringan. Sehingga model pemeriksaan perkaranya adalah peradilan cepat.

Hakim Pengadilan Negeri Gorontalo menyatakan bahwa e-Tilang si pelanggar cukup baca website dan langsung ke kejaksaan untuk membayarnya. Jadi sangatlah cepat, tidak usah pelanggar ke Pengadilan Negeri Gorontalo, Si pelanggar pun bisa mengakses informasi terkait jumlah yang harus dibayar dimana saja. Selain itu, penyelesaian perkara lalu lintas berbasis elektronik berbiaya murah. Sehingga tidak harus lagi menyediakan ongkos untuk menghadiri sidang ke pengadilan karena secara kebetulan si pelanggar dari kabupaten Bone Bolango yang cukup jauh dari Kota Gorontalo. ${ }^{17}$

\section{b. Pembayaran Rekening Bank}

Konsep e-Tilang selain mengefesienkan waktu dalam proses penyelesaian perkara lalu lintas dan angkutan jalan. Paling utama adalah mekanisme pembayaran denda (tilang). Bila pada umunya pembayaran denda dilakukan secara manual atau uang tunai. Maka pelaksanaan e-Tilang pembayaran dilakukan melalui tranfer uang melalui Bank.

17 Data Primer, Hasil Wawancara pada salah satu Hakim Pengadilan Negeri Gorontalo, Ngguli Liwar Mbani Awang, pada tanggal 24 Juli 2020. 
Adapun tata cara pembayaran e-Tilang sebagaimana pada gambar di bawah ini:

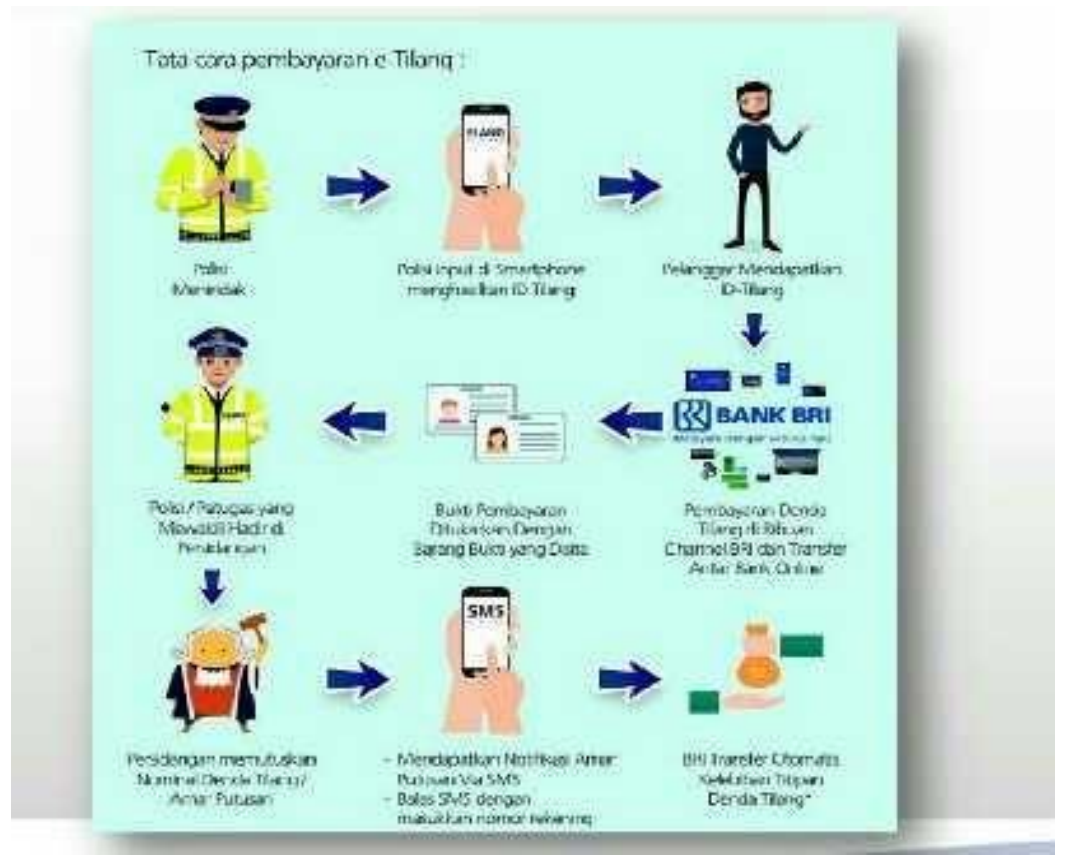

Sumber Gambar Unit Lalu Lintas Polres Bone Bolango

Berdasarkan gambar di atas, maka terlihat jelas tata cara pembayaran e-Tilang atau mekanisme penyelesaian perkara lalu lintas berbasis elektronik sangatlah erat kaitannya dengan sistem informasi dan teknologi. Mulai dari penindakan yang dilakukan oleh Polisi Lalu Lintas, si pelanggar mendapatkan ID Tilang yang terdiri dari jenis pelanggaran, jumlah denda maksimal yang dikenakan dan nama petugas yang melakukan penindakan. Si pelanggar kemudian membayar di Bank sebagaimana yang tercantum dalam ID Tilang. Setelah itu ke Kejaksaan Negeri dengan membawa bukti pembayaran via transfer melalui Bank untuk menukarkan dengan barang bukti yang disita.

Berdasarkan hasil penelitian terkait tata cara pembayaran e-Tilang, di lapangan berbeda-beda. Pertama, setelah si Pelanggar menerima ID Tilang melalui SMS, kemudian melakukan transfer melalui rekening bank. Setelah itu membawa bukti pembayaran e-Tilang ke kejaksaan negeri untuk ditukar dengan barang bukti yang disita. Kedua, setelah si Pelanggar mendapatkan ID Tilang melalui SMS, si pelanggar ke pengadilan negeri untuk mengikuti sidang dan membayar disana. Ketiga, setelah si pelanggar menerima ID Tilang melalui sms. Si pelanggar mendatangi pengadilan untuk melihat pengumuman sidang lalu lintas. Setelah itu pihak pengadilan 
mengarahkan untuk membayar di kejaksaan. Hakim Pengadilan Negeri Gorontalo menyatakan bahwa ketika sipelanggar datang, kita langsung arahkan ke bagian pengumuman hasil sidang tilang. Setelah itu kita arahkan membayar ke kejaksaan. Karena institusi kejaksaan adalah selaku pelaksana putusan atau eksekutor. ${ }^{18}$

\section{Hambatan-Hambatan Penyelesaian Perkara Lalu Lintas Berbasis Elektronik.}

Setelah pemberlakuan penyelesaian perkara lalu lintas dan angkutan jalan berbasis elektronik di seluruh Indonesia, maka banyak faktor penghambat yang mempengaruhi terlaksananya di lapangan. Adapun yang menjadi penghambat dalam pelaksanaan penyelesaian perkara lalu lintas berbasis elektronik di wilayah hukum Polres Bone Bolango adalah sebagai berikut:

\section{a. Faktor Hukum}

Penegakan hukum sangatlah dipengaruhi oleh banyak hal. Efektif tidaknya suatu aturan di lapangan bisa ditinjau dari regulasinya. Berbicara mengenai pelanggaran lalu lintas maka dari segi regulasi diatur dalam UU Nomor 22 Tahun 2009 tentang Lalu Lintas dan Angkutan Jalan.

UU Nomor 22 Tahun 2009 bukan hanya mengatur tentang jenis kendaraan bermotor umum maupun khusus, peran serta masyarakat, peran pemerintah pusat dan pemerintah daerah terkait lalu lintas dan angkutan jalan. Termasuk pula kejahatan dan pelanggaran lalu lintas serta lembaga yang berwenang dalam melakukan penegakan hukum.

Hanya saja bila membahas penyelesaian perkara lalu lintas berbasis elektronik. Justru salah satu penghambat dalam pelaksanaanya adalah dari segi hukumnya itu sendiri. Dalam UU Nomor 22 Tahun 2009 tidak ada satu pasal pun yang mengatur tentang mekanisme penyelesaian perkara lalu lintas berbasis elektronik.

18 Data Primer, Hasil Wawancara pada salah satu Hakim Pengadilan Negeri Gorontalo, Ngguli Liwar Mbani Awang, pada tanggal 24 Juli 2020. 
Penyelesaian perkara berbasis elektronik (e-Tilang) yang mulai diterapkan tahun 2017 di Provinsi Gorontalo menjadi dasar hukumnya hanyalah Peraturan Mahkamah Agung (PERMA) Nomor 12 Tahun 2016 tentang Tata Cara Penyelesaian Perkara Pelanggaran Lalu Lintas. Oleh sebab itu sangatlah wajar bila pelaksanaan penyelesaian perkara lalu lintas berbasis elektronik belumlah optimal dalam penegakannya.

Kurang optimalnya penyelesaian perkara berbasis elektronik (e-Tilang) disebabkan karena mekanisme ini tidak diatur secara jelas dalam UU Nomor 22 Tahun 2009 tentang Pelanggaran Lalu Lintas dan Angkutan Jalan. Dari segi turunan aturan internal seperti Peraturan Kapolri (PERKAP) pun tidak diatur. Selama ini kami hanya berdasarkan pada PERMA 12 Tahun 2016. ${ }^{19}$ Idealnya tata cara penyelesaian perkara lalu lintas berbasis elektronik diatur secara tersurat dalam UU Nomor 22 Tahun 2009. Agar jelas bagi lembaga yang terkait untuk menegakkannya. Karena harus kita ingat bahwa PERMA adalah peraturan kebijakan yang sifatnya lebih mengikat ke internalnya, padahal berbicara penegakan hukum terhadap pelanggaran lalu lintas terlibat lintas aparat penegak hukum.

\section{b. Faktor Sosialisasi}

Secara teori penegakan hukum, terdiri dari penindakan (represif) dan pencegahan (preventif). Langkah preventif merupakan tindakan awal yang dilakukan oleh penegak hukum dengan cara mengsosialisasikan ke masyarakat khususnya pengguna lalu lintas dan angkutan jalan. Wujud sosialisasi yang dilakukan baik berupa Goe to School atau kunjungan ke sekolah-sekolah maupun sosialisasi langsung di jalan. Materinya bisa membahas sekitaran peraturan perundangundangan yang terkait penegakan hukum pelanggaran lalu lintas.

Belum optimalnya pelaksanaan penyelesaian perkara lalu lintas berbasis elektronik di wilayah hukum Polres Bone Bolango ditandai dengan masih banyaknya masyarakat yang hadir ke Pengadilan Negeri Gorontalo untuk bersidang. Padahal bila instrumen sosialisasi terus digalakkan, tentunya tidak akan terjadi demikian. ETilang itu masyarakat tidak usah ke pengadilan cukup melihat situsnya, baru

${ }^{19}$ Data Primer, Hasil Wawancara pada Polisi Sarton Mohammad, pada tanggal 21 Juli 2020. 
membayar ke pengadilan. Akan tetapi, faktanya setiap hari jumat masyarakat selaku pelanggar tetap ada yang datang bersidang. ${ }^{20}$

Saya melihat masih kurang sosialisasi disini adalah teman-teman Polisi Lalu Lintas, mereka kurang memberi sosialisasi ke pelanggar padahal bisa cukup lihat saja di website pengadilan. Karena disana sudah ada Nomor Seri Tilang/No. Pembayaran, Tanda Nomor Kendaraan Bermotor, Nama Pelanggar dan Putusannya.

Kurangnya sosialisasi terkait e-Tilang atau penyelesaian perkara lalu lintas berbasis elektronik juga terkonfirmasi dari hasil wawancara dengan Bapak Brig.Pol Ramang Dunggio sosialisasi PERMA Nomor 12 Tahun 2016 khusus menyangkut penyelesaian perkara berbasis elektronik (e-Tilang) hanya serentak dilakukan pada awal tahun 2017. Untuk sosialisasi serupa sampai tahun 2019 tidak pernah dilakukan lagi. ${ }^{21}$

\section{c. Faktor Masyarakat}

Penegakan hukum berasal dari masyarakat, dan bertujuan untuk mencapai kedamaian di dalam masyarakat. Oleh karena itu, dipandang dari sudut tertentu, maka masyarakat dapat mempengaruhi penegakan hukum tersebut ${ }^{22}$. Hal ini sejalan dengan pameo hukum yang berbunyi "Ubi Societas Ibi Ius" yang artinya dimana ada masyarakat disitu ada hukum.

Tidak setiap kegiatan atau usahan yang bertujuan untuk melahirkan keharmonisan atau kedamaian dalam masyarakat secara otomatis masyarakat menaati aturan hukum tersebut. Dalam banyak kasus, justru masyarakat akan taat terhadap aturan disebabkan karena adanya sanksi-sanksi atau hukuman bagi si pelanggar. Atau mungkin warga masyarakat justru taat hukum karena ada petugas atau aparat penegak hukum. Misalnya, seorang pengguna jalan menerobos lampu jalan yang sementara berwarna merah. Akan tetapi, bila ada Polisi yang berdiri disana maka sudah pasti pengguna jalan tidak bakalan berani untuk menerobos lampu merah.

\footnotetext{
20 Data Primer, Hasil Wawancara pada salah satu Hakim Pengadilan Negeri Gorontalo, Ngguli Liwar Mbani Awang, pada tanggal 24 Juli 2020.

${ }^{21}$ Data Primer, Hasil Wawancara pada salah satu anggota Polri Kota Gorontalo Ramang Dunggio, pada tanggal 26 Juli 2020.

22 Soekanto, S. (1983). Faktor-faktor yang mempengaruhi Penegakan Hukum. Rajawali. Jakarta. h, 45
} 
Sehubungan dengan penelitian Penulis, pelaksanaan penyelesaian perkara lalu lintas berbasis elektronik justru terhambat karena faktor masyarakat. Hal tersebut disebabkan antara lain, Pertama, kurangnya sosialisasi kepada warga masyarakat yang harusnya dilakukan oleh unsur Kepolisian Lalu Lintas mengakibatkan masyarakat kurang informasi terkait penyelesaian perkara lalu lintas bebasis elektronik. Walhasil dari tahun 2017, PERMA Nomor 12 Tahun 2016 berlaku tetapi masih banyak masyarakat yang tetap ikut sidang di pengadilan.

Kedua, masyarakat lebih banyak yang memilih ikut sidang pelanggaran lalu lintas dibanding membayar di Bank sebagaimana ID Tilang yang si pelanggar peroleh. Penyebabnya adalah ID Tilang selain mencantumkan jenis pelanggaran juga denda maksimalnya. Tingginya denda berujung pada ketidakpercayaan masyarakat kepada Polisi Lalu Lintas.

\section{KESIMPULAN DAN SARAN}

Pelaksanaan penyelesaian perkara lalu lintas berbasis elektronik di daerah yaitu pelanggar menerima ID Tilang melalui SMS, kemudian melakukan transfer melalui rekening bank. Setelah itu membawa bukti pembayaran e-Tilang ke kejaksaan negeri untuk ditukar dengan barang bukti yang disita, kemudian si Pelanggar mendapatkan identitas Tilang melalui SMS, si pelanggar ke pengadilan negeri untuk mengikuti sidang dan membayar disana dan si pelanggar menerima ID Tilang melalui sms. Pelanggar mendatangi pengadilan untuk melihat pengumuman sidang lalu lintasdan pihak pengadilan mengarahkan untuk membayar di kejaksaan dan hambatanhambatan penyelesaian perkara lalu lintas berbasis elektronik yaitu faktor hukum, faktor social dan faktor masyarakat. Dalam pelaksanaan penyelesaian perkara lalu lintas kedepan seharusnya ini dituangkan di dalam undang undang sehingga penerapannya masih bisa lebih jelas, kemudian juga dibutuhkan sosialisasi yang lebih mendalam terkait dengan proses penindakannya sehingga masyarakat akan bisa memahami.

\section{REFERENSI}

Apriliana, L. Z., \& Jaya, N. S. P. (2019). Efektivitas Penggunaan E-Tilang Terhadap Pelanggaran Lalu Lintas Di Polres Magelang. Jurnal Komunikasi Hukum, 5(2). 
Fansuri, A. (2019). Sistem Tilang Elektronik terhadap Pelanggar Lalu Lintas Berdasarkan Perma Nomor 12 Tahun 2016. Ijtihad, 34(2).

Ginting, M. S., Suharyanto, B., Nugroho, E., Taufik, G. A., Damayana, G. P., Sholikin, M. N., ... \& Argama, R. (2015). Standardisasi Pengelolaan Perkara Pelanggaran Lalu Lintas di Pengadilan Negeri. Indonesian Center for Law and Policy Studies.

Nuna, M., Moonti, R. M., Tumuhulawa, A., \& Kodai, D. A. (2020). Kewenangan Penyelesaian Sengketa Tata Usaha Negara Terhadap Putusan Pemberhentian Tidak Dengan Hormat. University Of Bengkulu Law Journal, 5(2), 106-118.

Mulyono, A. T., \& Sandra, P. A. (2013). Evaluasi Kendala Dan Masalah Implementasi UU 22/2009 Tentang Llaj Terhadap Capaian Penyelenggaraan Jalan Nasional. Jurnal Transportasi, 13(2).

Setiyanto, S., Gunarto, G., \& Wahyuningsih, S. E. (2017). Efektivitas Penerapan Sanksi Denda E-Tilang Bagi Pelanggar Lalu Lintas Berdasarkan Undang-Undang Nomor 22 Tahun 2009 Tentang Lalu Lintas Dan Angkutan Jalan (Studi Di Polres Rembang). Jurnal Hukum Khaira Ummah, 12(4), 742-766

Sitepu, C., Rifai, E., \& Jatmiko, G. (2019). Analisis Pelaksanaan E-Tilang Dalam Upaya Pencegahan Praktik Pungutan Liar Yang Dilakukan Oleh Polisi Lalu Lintas (Studi Polres Metro Jakarta Selatan). POENALE: Jurnal Bagian Hukum Pidana, 7(2).

Soekanto, S. (1983). Faktor-faktor yang mempengaruhi Penegakan Hukum. Rajawali. Jakarta.

Suhariyanto, B. (2015). Penerapan Diversi untuk Menangani Problema Penyelesaian Perkara Pelanggaran Lalu Lintas di Pengadilan. Jurnal Hukum dan Peradilan, 4(1), 153-170.

Putra, R. H. W. (2020). Peran E-Tilang dalam Penindakan Pelanggaran Lalu Lintas Guna Mewujudkan Kamseltibcar Lantas di Wilayah Hukum Polres Banyumas. Police Studies Review, 4(1), 373-416.

Waluyo, B. (1991). Penelitian hukum dalam praktek. Sinar Grafika, Jakarta. 
Wahyuningsih, S. E., \& Iksan, M. (2019, November). The Benefits of the E-Traffic Ticketing (E-Tilang) System in the Settlement of Traffic Violation in Indonesia. In 2nd International Conference on Indonesian Legal Studies (ICILS 2019) (pp. 447-452). Atlantis Press.

\section{Internet:}

Yantina Debora, (2020). https://tirto.id/bVCo?utm source=CopyLink\&utm medium=Share, (diakses tanggal 4 Agustus 2020).https://tirto.id/polisi-terlibat-dalam-235-kasuspungli-bVCo (diakses tanggal 4 Agustus 2020)

https://news.detik.com/berita/d-2225696/banyak-calo-sidang-tilang-perlu-dievaluasi?utm source=copy url\&utm campaign=detikcomsocmed \&utm medium=btn\&ut $\underline{m \text { content=news }}$ (diakses tanggal 26 Juli 2020)

\section{PeraturanPerundang-Undangan}

UU Nomor 2 Tahun 2002 tentang Kepolisian Republik Indonesia

UU Nomor 22 Tahun 2009 tentang Lalu Lintas dan Angkutan Jalan

UU Nomor 31 Tahun 1999 Jo. UU Nomor 20 Tahun 2001 tentang Pemberatasan Tindak Pidana Korupsi

PERMA Nomor 12 Tahun 2016 tentang Tata Cara Penyelesaian Perkara Lalu Lintas 